DOI: $10.19195 / 0137-1134.114 .44$

\author{
ANNA WALASZEK-PYZIOE \\ Uniwersytet Jagielloński \\ anna.walaszek-pyziol@uj.edu.pl \\ WOJCIECH PYZIOŁ \\ Uniwersytet Jagielloński \\ wojciech.pyziol@uj.edu.pl
}

\title{
KILKA REFLEKSJI NA TEMAT PROBLEMATYKI WKŁADÓW DO SPÓŁKI JAWNEJ
}

\begin{abstract}
Abstrakt: Spółka jawna nie może być spółką „bezwkładową”, to znaczy taką, w której choćby jeden ze wspólników nie byłby zobowiązany do wniesienia wkładu. Spółka jawna może jednak powstać jako podmiot prawa, mimo iż nie wniesiono do niej jeszcze jakichkolwiek wkładów — wniesienie wkładów do spółki jest zobowiązaniem wspólników, które może być wykonane nie tylko po zawiązaniu spółki, lecz także w późniejszym terminie. Umowa spółki może również przewidywać, że poszczególni wspólnicy będą zobowiązani wnieść swój wkład po zawarciu umowy, ale jeszcze przed zarejestrowaniem spółki.
\end{abstract}

Słowa kluczowe: spółka jawna, wkłady, umowa spółki

\section{ZOBOWIĄZANIE DO WNIESIENIA WKŁADU}

1. Zgodnie z art. 3 kodeksu spółek handlowych (dalej: k.s.h.) konstrukcja prawna każdej spółki handlowej, a zatem także konstrukcja prawna spółki jawnej, zakłada obowiązek każdego wspólnika wniesienia wkładu do spółki ${ }^{1}$. Oznacza to, że spółka jawna nie może być spółką „,bezwkładową”, to znaczy taką, w której choćby jeden ze wspólników nie byłby zobowiązany do wniesienia wkładu. Wyklucza to więc możliwość tworzenia i funkcjonowania spółek jawnych, których

1 Piśmiennictwo (monografie, artykuły i komentarze) dotyczące spółek jawnych (w tym analizujące problematykę wkładów do takich spółek) jest bardzo bogate. Podstawowe znaczenie należy przypisać wybitnej monografii K. Kopaczyńskiej-Pieczniak, Pozycja prawna wspólnika spótki jawnej (Warszawa 2013). Spośród innych pozycji na wymienienie zasługują w szczególności opracowania A. Kidyby, Handlowe spótki osobowe (Warszawa 2010) oraz Kodeks spółek handlowych, t. 1. Komentarz do art. 1-150 (Warszawa 2017). Zob. też M. Litwińska-Werner, [w:] System Prawa Handlowego, t. 2. Prawo spótek handlowych, red. S. Włodyka, Warszawa 2012. 
wspólnicy byliby zobowiązani jedynie do określonego współdziałania niepowiązanego z obowiązkiem wniesienia wkładu (na przykład do współdziałania polegającego tylko na zaniechaniu konkurencji w określonych dziedzinach bądź we wskazanych miejscach albo na uzgodnieniu wspólnej strategii działania wobec osób trzecich).

Jednocześnie należy podkreślić, że spółka jawna może powstać jako podmiot prawa, mimo iż nie wniesiono do niej jeszcze jakichkolwiek wkładów. Wniesienie wkładów do spółki jest zobowiązaniem wspólników, które może być wykonane nie tylko po zawiązaniu spółki, lecz także w późniejszym terminie. W tym sensie możliwe jest istnienie spółki de facto „bezwkładowej” nawet przez dłuższy czas po zarejestrowaniu spółki. Jednak okoliczność, iż wkłady „umówione”, ale jeszcze „niewniesione realnie” do spółki nie stanowią podstawy do określenia wysokości tak zwanego udziału kapitałowego poszczególnych wspólników (art. 50 § 1 k.s.h.) oraz że spółka dysponuje w omawianym wypadku roszczeniem wobec wspólników o wniesienie wkładu, powinna skłaniać wspólników do możliwie szybkiego wniesienia wkładu, do którego byli zobowiązani z mocy umowy spółki²

2. Zgodnie $\mathrm{z}$ art. $25 \mathrm{k}$.s.h. określenie $\mathrm{w}$ umowie spółki wnoszonych przez każdego wspólnika wkładów i ich wartości jest elementem koniecznym tej umowy. Ponieważ sama umowa spółki powinna być zawarta na piśmie pod rygorem nieważności (art. 23 k.s.h.), niezamieszczenie w umowie postanowienia przewidującego zobowiązanie wszystkich wspólników do wniesienia oznaczonego wkładu o oznaczonej wartości skutkuje nieważnością całej umowy.

3. W myśl art. 48 § 2 k.s.h. „wkład wspólnika może polegać na przeniesieniu lub obciążeniu własności rzeczy lub innych praw, a także na dokonaniu innych świadczeń na rzecz spółki”.

Z przytoczonej syntetycznej formuły ustawowej wynika, że przedmiotem umówionego wkładu wspólnika do spółki może być co do zasady każde świadczenie, które wspólnicy określili tym mianem w umowie spółki. W szczególności w grę wchodzą tu: 1. wkłady pieniężne, 2. prawo własności nieruchomości, 3. prawo własności rzeczy ruchomej, 4. prawo do przedsiębiorstwa w rozumieniu art. 55.1 k.c., 5. prawa rzeczowe inne niż prawo własności (przeniesione na spółkę bądź ustanowione na jej rzecz prawa z papierów wartościowych), 6. prawa ,udziałowe" (na przykład w spółkach kapitałowych), 7. prawa na dobrach niematerialnych, 8. wierzytelności wspólnika wobec osób trzecich, 9. oddanie bądź udostępnienie spółce rzeczy do używania oraz 10. ,inne” świadczenia na rzecz spółki, w tym świadczenie usług lub pracy. Te ostatnie wykazują specyfikę polegającą na tym, iż z reguły są wnoszone permanentnie po powstaniu spółki przez oznaczony bądź nieoznaczony czas, co skutkuje trudnościami w oznaczeniu ich wartości. Ponadto wkłady te charakteryzują się brakiem tak zwanej wartości zbywczej, co z kolei

\footnotetext{
${ }^{2}$ Zob. m.in. A. Kidyba, Handlowe spótki osobowe, s. 66 n. i wskazana tam literatura.
} 
powoduje kontrowersje doktrynalne co do tego, czy mogą być (lub nie) zaliczane na poczet tak zwanego udziału kapitałowego wspólnika wnoszącego taki wkład.

4. Należy przyjąć, iż umowa spółki jest co zasady „wystarczającym” źródłem zobowiązania wspólnika do wniesienia wkładu. Umowa spółki niejako zastępuje inną umowę o skutku zobowiązującym lub zobowiązująco-rozporządzającym, na przykład umowę o przelew wierzytelności bądź umowę o sprzedaży rzeczy ruchomej lub umowę najmu czy dzierżawy. Stwierdzenie to można także odnieść do wkładów polegających na świadczeniu usług lub pracy.

Jest jednak kwestią dyskusyjną, czy od wskazanej reguły zachodzą wyjątki i na czym ewentualnie mogą one polegać. W szczególności problemem jest, czy do kwestii wniesienia wkładu przepisy art. 23 oraz 25 k.s.h. wprowadzają jakieś rozróżnienia w stosunku do przepisów k.c. (lub przepisów innych ustaw) dotyczących sposobu przenoszenia praw danego rodzaju. Artykuł 23 wprowadza wymóg formy pisemnej pod rygorem nieważności umowy spółki, a taka umowa musi zawierać zobowiązanie każdego ze wspólników do wniesienia określonego wkładu (art. 25 pkt 2 w zw. z art. 3 k.s.h.). Trzeba nadmienić, że art. 23 k.s.h. nie zawiera jakiegokolwiek zastrzeżenia dotyczącego wypadków, w których przeniesienie na spółkę - tytułem wkładu - dotyczy praw, których przenoszenie „w ogóle” wymaga dochowania innej formy szczególnej.

Kwestia, o której mowa, odnosi się zwłaszcza do sytuacji, w której wspólnik — w umowie spółki — zobowiązuje się do przeniesienia na spółkę prawa własności nieruchomości. W doktrynie przyjmuje się, iż w takiej sytuacji umowa spółki powinna być zawarta $\mathrm{w}$ formie aktu notarialnego, ponieważ zarówno umowa zobowiązująca do przeniesienia własności nieruchomości, jak i umowa przenosząca własność nieruchomości wymagają dochowania formy aktu notarialnego (art. 158 k.c.) $)^{3}$. Analogicznie w doktrynie ocenia się inne przypadki, jeśli przeniesienie jakiegoś prawa na spółkę (jego obciążenie lub ustanowienie na rzecz spółki) wymaga dochowania formy szczególnej innej niż forma pisemna pod rygorem nieważności. Oznaczać by to musiało — paradoksalnie — iż umowa spółki jawnej przewidująca zobowiązanie wspólnika do przeniesienia na spółkę — tytułem wkładu - prawa własności nieruchomości, zawarta bez zachowania formy aktu notarialnego musiałaby zostać uznana za nieważną (art. 23 k.s.h.).

Można w tym względzie próbować bronić innego stanowiska. Otóż wydaje się, iż zamiarem ustawodawcy było — jeśli chodzi o formę umowy spółki — jednolite traktowanie wszystkich przypadków, zatem także takich, w których wkład wspólnika ma polegać na wniesieniu do spółki własności nieruchomości. Jeśli przyjąć takie założenie, to możliwe stałoby się interpretowanie art. 23 k.s.h. jako przepisu szczególnego w relacji do przepisów innych ustaw regulujących formę

${ }^{3}$ Zob. m.in. S. Sołtysiński, [w:] S. Sołtysiński et al., Kodeks spółek handlowych, t. 1, Warszawa 2012, s. 401-403. 
czynności prawnych, przynajmniej w odniesieniu do czynności o skutku wyłącznie zobowiązującym. W szczególności można by wówczas twierdzić, że art. 23 k.s.h. wyłącza zastosowanie art. 158 zd. 1 k.c., który ustanawia wymóg formy aktu notarialnego dla umowy zobowiązującej do przeniesienia własności nieruchomości i zarazem wyłącza zastosowanie art. 155 § 1 k.c. przewidującego zasadę „podwójnego" (zobowiązująco-rozporządzającego) skutku umowy zobowiązującej do przeniesienia własności rzeczy. Proponowany sposób wykładni art. 23 k.s.h. umożliwiałby zachowanie ważności umowy spółki jawnej zawierającej zobowiązanie do wniesienia wkładu w postaci własności nieruchomości, ale zawartej tylko $\mathrm{w}$ formie pisemnej, a nie w formie aktu notarialnego. Natomiast wymóg formy aktu notarialnego pozostawałby aktualny w stosunku do — koniecznej w omawianej sytuacji - dodatkowej czynności prawnej, jaką jest czynność prawna (rozporządzająca) przenosząca własność w wykonaniu zobowiązania zawartego w umowie spółki (art. 158 zd. 2 k.c.).

Jednocześnie należy mieć na względzie, iż zobowiązanie każdego ze wspólników do wniesienia wkładu jest co do zasady zobowiązaniem wobec „spółki jawnej”, a zatem wobec podmiotu formalnie istniejącego (art. $25 \S 1$ k.s.h.). Oznacza to, iż skuteczność tego zobowiązania jest uzależniona (a co najmniej „odroczona”) od tego, czy spółka zostanie wpisana do rejestru przedsiębiorców. Owo uzależnienie jest - naszym zdaniem — przykładem tak zwanego warunku prawnego (conditio iuris). Taka kwalifikacja jest o tyle uzasadniona, że wpis spółki do rejestru wprawdzie powinien, ale może w ogóle nie nastąpić.

5. Jak już wzmiankowano, art. 25 pkt 2 k.s.h. ustanawia wymóg oznaczenia w umowie wartości wkładów wnoszonych przez poszczególnych wspólników. Problemy z tym związane odnoszą się zwłaszcza do wkładów niepieniężnych (aportów) oraz do wkładów mających polegać na świadczeniu pracy lub usług.

Kodeks spółek handlowych nie zawiera jednak żadnych reguł co do sposobu wyceny wkładów niepieniężnych. W szczególności nie nakazuje wyceny według rzeczywistej (rynkowej) wartości danego wkładu. Oznacza to, iż - w granicach wyznaczonych przez art. 353.1 k.c. - wspólnicy mogą wycenić wnoszone wkłady zasadniczo w sposób dowolny; mogą zatem je zarówno „niedoszacować”, jak i ,przeszacować”. Należy nadmienić, iż dokonana w umowie spółki wycena wartości wkładów ma walor li tylko „wewnętrzny” (czyli jedynie dla samych wspólników). Z punktu widzenia wierzycieli spółki wycena wkładów dokonana przez wspólników w umowie spółki (ewentualne ich niedoszacowanie lub przeszacowanie) nie ma praktycznego znaczenia, albowiem bez względu na umownie określoną wartość wkładów i tak mają oni dostęp do majątków osobistych wspólników.

Jest kwestią dyskusyjną, czy swoboda wspólników w zakresie ustalania wartości wnoszonych przez nich wkładów ma walor ogólny, czy też odnosi się wyłącznie do spółek niepodlegających rygorom przewidzianym w ustawie o rachunkowości 
z 1994 roku. Zgodnie z art. 2 ust. 1 przepisy tej ustawy stosuje się między innymi do spółek jawnych, których ,przychody netto ze sprzedaży towarów, produktów i operacji finansowych za poprzedni rok obrotowy wyniosły co najmniej równowartość 1200000 euro". Takie spółki są zobowiązane do prowadzenia ksiąg rachunkowych według zasad szczegółowo określonych w ustawie.

Ustawa o rachunkowości odróżnia zatem „małe” spółki jawne od „dużych”. Co do „małych” spółek jawnych przedstawione ustalenia są aktualne w całej rozciągłości. Natomiast gdy chodzi o spółki „duże”, w doktrynie wyrażany jest pogląd, iż określenie wartości wkładów powyżej wartości rynkowej (godziwej) jest niedopuszczalne ${ }^{4}$. W istocie art. 28 ustawy o rachunkowości określa kryteria wyceny aktywów i pasywów podmiotu podlegającego jej przepisom. Ich stosowanie ma skutkować wyceną odpowiadającą „rzeczywistej” wartości danego aktywu lub pasywu. Przykładowo nieruchomość powinna być wyceniona „według ceny rynkowej bądź inaczej określonej wartości godziwej” (art. 28 ust. 1 pkt la ustawy o rachunkowości). Należy jednak mieć na względzie, że na gruncie ustawy o rachunkowości wycena aktywów (pasywów) ma na celu stworzenie podstaw do sporządzenia sprawozdania finansowego danego podmiotu za dany rok obrachunkowy. Jest zatem dokonywana corocznie, co z natury rzeczy zakłada zmienność wyników takiej wyceny. W tym sensie można mówić o „zewnętrznym” charakterze (funkcji) wyceny. Natomiast - jak już stwierdzono - wycena wartości wkładów dokonana w umowie spółki pełni zupełnie inną — „wewnętrzną" funkcję. Stanowi ona podstawę do ustalenia wysokości udziałów kapitałowych poszczególnych wspólników oraz podstawę do określenia udziału wspólników w podziale majątku spółki w razie jej likwidacji (art. 82 § 2 k.s.h.). W związku $\mathrm{z}$ tym nie ma powodu, aby odmawiać wspólnikom prawa do dowolnego (co do zasady, to znaczy z uwzględnieniem art. 58 oraz $353^{1}$ k.c.) określania wartości ich wkładów w umowie spółki także w wypadku spółek ,dużych”.

6. Wycena (w umowie spółki) wartości wkładów polegających na świadczeniu określonej pracy lub usług nie rodzi problemów w sytuacjach, gdy owa praca bądź usługi mają być wykonane w z góry określonym czasie. Inaczej jest, gdy praca lub usługi mają być świadczone przez czas nieoznaczony, czyli przez cały okres trwania spółki. Sprecyzowanie w umowie (czyli niejako „z góry”) wartości wkładu polegającego na świadczeniu pracy lub usług w sposób permanentny musiałoby skutkować postępującą „,deprecjacją” tego rodzaju wkładów, jako że nie jest możliwe określenie ilości pracy (usług), jakie dany wspólnik będzie zobowiązany w przyszłości świadczyć. Dlatego też należy przyjąć — na zasadzie wyjątku od reguły — że w omawianym wypadku wystarczające będzie określenie w umowie jedynie podstaw do ustalania w przyszłości wartości wkładów, jakie będą wniesio-

${ }^{4}$ Zob. m.in. ibidem, s. 424. 
ne w czasie trwania spółki. Można to zrealizować poprzez oznaczenie w umowie wartości jednostkowej danej pracy (na przykład pracy trwającej jeden dzień) albo wartości jednostkowej danej usługi.

7. Zawarta w art. 25 pkt 2 (w zw. z art. 23) k.s.h. regulacja dotycząca skutków nieokreślenia w umowie wartości wkładów wnoszonych przez każdego ze wspólników wydaje się jednoznaczna. Sprawę tę komplikuje jednak treść art. 48 $\S 1$ k.s.h., stanowiącego, że „w razie wątpliwości uważa się, że wkłady wspólników są równe". Przytoczony przepis (przeniesiony niefrasobliwie przez twórców k.s.h. $z$ dawnego kodeksu handlowego) pozostaje $\mathrm{z}$ art. 25 pkt 2 k.s.h. w ewidentnej sprzeczności. Jako przepis obowiązujący wymaga jednak kilku słów komentarza.

Jak się wydaje, art. $48 \S 1$ k.s.h. może znaleźć zastosowanie tylko w nielicznych przypadkach. Po pierwsze, wówczas gdy w umowie spółki określono jedynie łączną wartość wkładów bez przypisania konkretnych wartości poszczególnym wspólnikom. W takim wypadku owa łączna wartość będzie dzielona przez liczbę wspólników (według „głów”). Operacja taka może jednak skutkować dość zaskakującymi rezultatami, jeśli część wspólników ma wnieść wkłady pieniężne, a pozostali wkłady niepieniężne (na przykład własność nieruchomości). Przykładowo, jeśli łączna wartość wkładów wnoszonych przez sześciu wspólników ma wynosić 600 tys. zł, to należy przyjmować, że każdemu wspólnikowi należy przypisać wkład o wartości 100 tys. zł. Jeżeli jednak wartość rynkowa nieruchomości wnoszonej do spółki przez jednego ze wspólników wynosi na przykład 500 tys. zł, to wówczas będziemy mieli do czynienia ze swoistym ,pokrzywdzeniem" takiego wspólnika. Możliwość zaistnienia takiej sytuacji powinna stanowić bodziec dla wspólników, aby jednak sprecyzowali wartość wkładów w odniesieniu do każdego z nich.

Po drugie, art. $48 \S 1$ k.s.h. może znaleźć zastosowanie w wypadku, gdy w umowie spółki określono wartość wkładu tylko jednego wspólnika (albo jednakowo wyceniono wartość wyłącznie niektórych wspólników). Także w takiej sytuacji rezultaty zastosowania omawianego przepisu mogą zostać uznane za zaskakujące. Przykładowo, jeśli w umowie przewidziano wkład pieniężny jednego ze wspólników w kwocie 1 tys. zł, wartości wkładów niektórych pozostałych wspólników nie określono, a jednocześnie w umowie przewidziano, że inny wspólnik ma wnieść do spółki własność oznaczonej nieruchomości, której wartość rynkowa wynosi 200 tys. zł, to wówczas trzeba uznać, iż wartość wkładu wspólnika wnoszącego taką nieruchomość będzie wynosić 1 tys. zł.

Natomiast art. $48 \S 1$ k.s.h. nie będzie mógł znaleźć zastosowania wówczas, gdy w umowie spółki określono — ale w sposób nierówny — wartość wkładów niektórych (nie wszystkich) wspólników.

Już tylko te dwa przytoczone przykłady świadczą o tym, iż wprowadzenie do k.s.h. reguły przewidzianej w art. $48 \S 1$ k.s.h. (stanowiącej kopię reguły zawartej w art. $102 \S 1$ dawnego k.h.) jest zabiegiem chybionym. De lege ferenda przepis ten powinien zostać uchylony. 


\section{WNIESIENIE WKŁADU}

1. W wykonaniu zobowiązania do wniesienia wkładu wspólnicy powinni faktycznie wnieść swoje wkłady. Z art. 48 § 2 k.s.h. wynika pośrednio, iż wniesienie wkładu do spółki skutkuje przysporzeniem majątkowym na jej rzecz. Skutkiem takiego przysporzenia może być powstanie albo powiększenie aktywów mających — przynajmniej teoretycznie — wartość ,zbywczą”, rozumianą jako realna możliwość ich spieniężenia i przeznaczenia na zaspokojenie należności wierzycieli spółki. Wśród tego rodzaju aktywów wymienić można na przykład środki pieniężne na rachunkach bankowych spółki oraz ruchomości i nieruchomości wniesione do spółki.

Jednak o przysporzeniu na rzecz spółki można mówić również wówczas, gdy wspólnik wnosi do spółki wkład polegający na świadczeniu przez niego usług lub innych form pracy na rzecz spółki. Wkłady tego rodzaju stanowią część majątku spółki, jako że w takim wypadku spółka uzyskuje względem takiego wspólnika roszczenie o realne spełnienie obowiązku wniesienia wkładu. Takie roszczenie powiększa zatem teoretycznie aktywa spółki (jako przysługująca jej wierzytelność), choć jest oczywiste, iż nie jest możliwe „fizyczne” zmuszenie wspólnika do wykonania danej usługi czy określonej pracy. Wątpliwe jest w związku z tym twierdzenie, iż spółka jawna może zostać utworzona bez jakiegokolwiek majątku. Wkłady, o których mowa, nie mają wprawdzie wartości ,zbywczej” w powyższym znaczeniu tego słowa. Mogą być natomiast podstawą do określenia wysokości tak zwanego udziału kapitałowego wspólnika wnoszącego tego rodzaju wkład. Poza tym w grę wchodzi ewentualna odpowiedzialność wspólnika za niewykonanie obowiązku wykonania usług lub świadczenia pracy, a roszczenia odszkodowawcze z tego tytułu z pewnością stanowią element majątku spółki (art. 471 k.c. w zW. z art. 3 k.s.h.).

2. Wniesienie wkładów do spółki jest obowiązkiem wspólników, który może być wykonany nie tylko po zarejestrowaniu spółki, lecz także w późniejszym terminie. Wspólnicy mają swobodę decyzji co do oznaczenia terminu wniesienia wkładów przez poszczególnych wspólników. Jest to zrozumiałe, gdyż nie każdy umówiony wkład może być przydatny dla spółki natychmiast po jej powstaniu jako odrębnego podmiotu prawa.

Jeżeli umowa spółki nie zawiera postanowienia określającego termin wniesienia wkładu przez poszczególnych wspólników, to w grę wchodzić będzie zastosowanie art. 455 k.c. W takim wypadku wspólnik powinien wnieść swój wkład niezwłocznie po wezwaniu dokonanym przez wierzyciela, to znaczy spółkę jawną reprezentowaną przez któregokolwiek wspólnika mającego prawo do reprezentowania spółki.

3. Umowa spółki może przewidywać, iż poszczególni wspólnicy będą zobowiązani wnieść swój wkład po zawarciu umowy, ale jeszcze przed zarejestrowaniem spółki. W takim wypadku nie jest możliwe wniesienie wkładu „do spółki” 
(skoro ona jeszcze nie istnieje jako odrębny podmiot prawa). Możliwe jednak wydaje się wniesienie wkładu „na rachunek przyszłej spółki”, co pośrednio wynika z brzmienia art. $25^{1} \S 2$ k.s.h. Należy w tym miejscu zaznaczyć, że taki okres „przejściowy” (,przedspółka”) nie powinien w zasadzie trwać dłużej niż około 3 tygodni. Wynika to z art. 22 oraz 20a ustawy o Krajowym Rejestrze Sądowym, przy czym do terminów określonych w tych przepisach należy dodać dni pocztowe i ewentualne dni wolne od pracy. Ów okres przejściowy może jednak z różnych przyczyn się wydłużyć i to niekiedy znacznie. Sprawia to, iż kwestia ewentualnego wnoszenia wkładów jeszcze przed wpisem do rejestru nie jest problemem wyłącznie teoretycznym. Można zatem postawić pytanie, na podstawie jakiej konstrukcji prawnej byłoby możliwe wnoszenie wkładów do przyszłej spółki (czyli do „przedspółki”).

Jedynym racjonalnym rozwiązaniem wydaje się w omawianym zakresie zastosowanie w drodze analogii (i zarazem odpowiednio) niektórych przepisów k.c. o spółce cywilnej (do której „,przedspółka” jawna wykazuje bardzo daleko idące podobieństwa). Należy w związku z tym przyjąć, że wspólnicy działający w ramach „przedspółki” działają w imieniu wszystkich wspólników (z czego wynika, iż mamy tu do czynienia z wielością dłużników i wielością wierzycieli), mienie zaś przedspółki pochodzące z wniesionych wkładów tworzy wspólność łączną wszystkich wspólników. Umożliwia to zawieranie niezbędnych na tym etapie umów, na przykład umowy rachunku bankowego, umów o pracę, a także wnoszenie wkładów do „przedspółki” (w tym własności nieruchomości). Nie ma żadnych przeszkód do uznania, iż wspólnik działający „,w imieniu” i „na rachunek” przyszłej spółki jawnej może jednocześnie działać w „imieniu i na rachunek przedspółki” (czyli w imieniu i na rachunek wszystkich wspólników), skoro ,przedspółka” (jako pewien stan prawny) nie istnieje jednocześnie ze spółką jawną, ale tę ostatnią poprzedza.

Jeśli zaprezentowane rozumowanie uznać za poprawne, można i należy wyprowadzić z niego konsekwencję w postaci uznania, że spółka jawna z chwilą wpisu do rejestru staje się automatycznie prawnym następcą ,przedspółki”, czyli działających łącznie wspólników. Oznacza to, że stosunki prawne powstałe na etapie przedspółki trwają nadal po zarejestrowaniu spółki, a treść tych stosunków pozostaje ta sama - zmienia się tylko ich podmiot, to znaczy na miejsce ,przedspółki” (czyli ogółu wspólników) wchodzi zarejestrowana spółka jako odrębny formalnie podmiot prawa.

W związku z tym wkłady wniesione do ,,przedspółki”, które stanowiły wspólność łączną wszystkich wspólników, staną się składnikami majątku spółki jawnej jako takiej. Jak już wspomniano, omawiana sukcesja nastąpi automatycznie bez konieczności powtarzania dokonanych na etapie „przedspółki” czynności prawnych (na przykład zawarcia umowy przenoszącej własność nieruchomości stanowiącej wkład do spółki między wspólnikami jako dotychczasowymi współwłaścicielami a spółką jawną). Oczywiście w wielu tego rodzaju wypadkach może okazać się 
konieczne dokonanie pewnych czynności formalnych (na przykład wpisanie do księgi wieczystej spółki jawnej jako właściciela nieruchomości na miejsce wspólników czy zawiadomienie określonych organów).

W możliwym przypadku polegającym na tym, iż spółka jawna ostatecznie nie powstanie (nieważne z jakich przyczyn) analogiczne zastosowanie odnośnych przepisów o spółce cywilnej (art. 871 i 875 k.c.) będzie właściwym instrumentem rozwikłania problemów będących konsekwencją niedojścia do skutku ,przedsięwzięcia", jakim miało być utworzenie spółki jawnej jako podmiotu prawa. Kwestia ta jest jednak dyskusyjna ${ }^{5}$.

\title{
SOME REFLECTIONS ON THE ISSUE OF CONTRIBUTIONS TO THE GENERAL PARTNERSHIP
}

\author{
Summary
}

A general partnership cannot be a partnership in which even only one of the partners would not be obliged to contribute. A general partnership may, however, arise as a legal entity, although no contributions have been made to it yet - making contributions to the company is an obligation of partners, which may be performed not only after the formation of the company, but also at a later date. The articles of association may provide that individual partners will be required to make their contribution after the conclusion of the articles, but before the company is registered.

Keywords: general partnership, contributions, articles of association

\section{BIBLIOGRAFIA}

Kidyba A., Handlowe spótki osobowe, Warszawa 2010.

Kidyba A., Kodeks spótek handlowych, t. 1. Komentarz do art. 1-150, Warszawa 2017.

Kopaczyńska-Pieczniak K., Pozycja prawna wspólnika spótki jawnej, Warszawa 2013.

Pyzioł W., ,Spótka” jawna w fazie „początkowej”, [w:] Rozprawy z prawa prywatnego. Księga jubileuszowa dedykowana Profesorowi Wojciechowi Popiołkowi, red. M. Pazdan et al., Warszawa 2017.

Sołtysiński S., Szajkowski A., Szumański A., Szwaja J., Kodeks spółek handlowych, t. 1, Warszawa 2012.

System Prawa Handlowego, t. 2. Prawo spółek handlowych, red. S. Włodyka, Warszawa 2012.

5 Dokładniej na ten temat zob. W. Pyzioł, „Spółka” jawna w fazie „początkowej”, [w:] Rozprawy z prawa prywatnego. Księga jubileuszowa dedykowana Profesorowi Wojciechowi Popiołkowi, red. M. Pazdan et al., Warszawa 2017, s. 559-564. 